BRAVZULIAN JOURNAL

OF MEDICAL AND BIOLOGICAL RESH.ARCH

www.bjournal.com.br
ISSN 0100-879X

Volume 44 (6) 497-605 June 2011

BIOMEDICAL SCIENCES

AND

CLINICAL INVESTIGATION

Braz J Med Biol Res, June 2011, Volume 44(6) 538-545

doi: 10.1590/S0100-879X2011007500037

Efficacy of geraniol but not of $\beta$-ionone or their combination for the chemoprevention of rat colon carcinogenesis

A. Vieira, R. Heidor, M.T. Cardozo, C. Scolastici, E. Purgatto, T.M. Shiga, L.F. Barbisan, T.P. Ong and F.S. Moreno

The Brazilian Journal of Medical and Biological Research is partially financed by

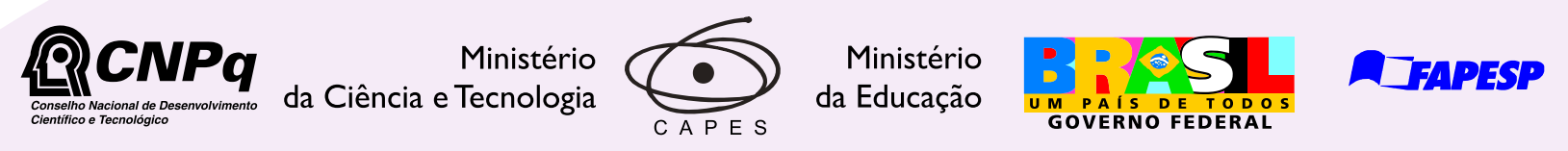

Institutional Sponsors
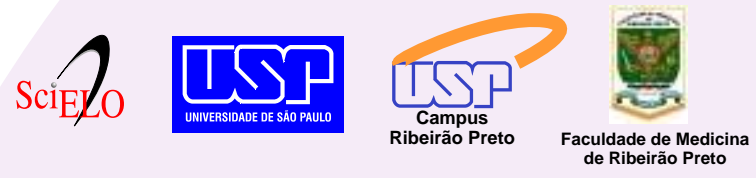
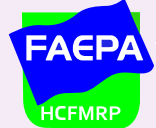

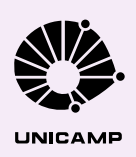

Ф SHIMADZU

Hotsite of proteomics metabolomics developped by:

GE Healthcare

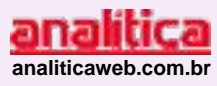

Thermo 


\title{
Efficacy of geraniol but not of $\beta$-ionone or their combination for the chemoprevention of rat colon carcinogenesis
}

\author{
A. Vieira ${ }^{1}$, R. Heidor ${ }^{1}$, M.T. Cardozo ${ }^{1}$, C. Scolastici ${ }^{1}$, E. Purgatto ${ }^{2}$, T.M. Shiga ${ }^{2}$, \\ L.F. Barbisan ${ }^{3}$, T.P. Ong ${ }^{1}$ and F.S. Moreno ${ }^{1}$ \\ ${ }^{1}$ Laboratório de Dieta, Nutrição e Câncer, ${ }^{2}$ Laboratório de Química e Bioquímica de Alimentos, \\ Departamento de Alimentos e Nutrição Experimental, Faculdade de Ciências Farmacêuticas, \\ Universidade de São Paulo, São Paulo, SP, Brasil \\ ${ }^{3}$ Departamento de Morfologia, Instituto de Biociências, \\ Universidade Estadual Paulista, Botucatu, SP, Brasil
}

\begin{abstract}
$\beta$-ionone $(\beta \mathrm{I})$, a cyclic isoprenoid, and geraniol (GO), an acyclic monoterpene, represent a promising class of dietary chemopreventive agents against cancer, whose combination could result in synergistic anticarcinogenic effects. The chemopreventive activities of $\beta \mathrm{I}$ and $\mathrm{GO}$ were evaluated individually or in combination during colon carcinogenesis induced by dimethylhydrazine in 48 3-week-old male Wistar rats (12 per group) weighing 40-50 g. Animals were treated for 9 consecutive weeks with $\beta \mathrm{I}$ (16 $\mathrm{mg} / 100 \mathrm{~g}$ body weight), GO (25 mg/100 g body weight), $\beta$ I combined with $\mathrm{GO}$, or corn oil (control). Number of total aberrant crypt foci (ACF) and of ACF $\geq 4$ crypts in the distal colon was significantly lower in the GO group (66 \pm 13 and $9 \pm 2$, respectively) compared to control (102 \pm 9 and $17 \pm 3$ ) and without differences in the $\beta I(91 \pm 11$ and $14 \pm 3)$ and $\beta I+G O$ groups (96 \pm 5 and $19 \pm 2$ ). Apoptosis level, identified by classical apoptosis morphological criteria, was significantly higher in the GO group (1.64 \pm 0.06 apoptotic cells $\left./ \mathrm{mm}^{2}\right)$ compared to control $\left(0.91 \pm 0.07\right.$ apoptotic cells $\left./ \mathrm{mm}^{2}\right)$ in the distal colon. The GO group presented a 0.7 -fold reduction in $\mathrm{Bcl}-2$ protein expression (Western blot) compared to control. Colonic mucosa concentrations of $\beta \mathrm{I}$ and GO (gas chromatography/mass spectrometry) were higher in the $\beta I$ and GO groups, respectively, compared to the control and $\beta I+G O$ groups. Therefore, GO, but not $\beta I$, represents a potential chemopreventive agent in colon carcinogenesis. Surprisingly, the combination of isoprenoids does not represent an efficient chemopreventive strategy.
\end{abstract}

Key words: Colon; Carcinogenesis; Chemoprevention; $\beta$-ionone; Geraniol; Isoprenoid; Acyclic monoterpene

\section{Introduction}

Colon cancer, which is the second most prevalent type of cancer in the world, is an important public health problem that is related to life style, especially eating habits (1).

Bioactive compounds present in foods, such as isoprenic derivatives found in fruits and vegetables, are potential chemopreventive agents against cancer $(2,3)$. Promising dietary isoprenoids are $\beta$-ionone $(\beta \mathrm{I})$, a cyclic isoprenoid, the product of $\beta$-carotene degradation, which is present mainly in grapes and wine aromatizers, and geraniol (GO), an acyclic monoterpene, which is an important constituent of the essential oils of ginger, lemon, lime, orange, and nutmeg (Figure 1). Both compounds are of interest to the detergent, perfume and food industries because of their floral aromatics and antifungal and antioxidant properties $(4,5)$.
Several in vitro studies have shown that $\beta I$ and GO suppressed cell proliferation and/or stimulated apoptosis in diverse tumor lines, including Caco-2 human colon adenocarcinoma cells $(6,7)$. In the few available in vivo studies, both compounds exerted chemopreventive activity against hepatocarcinogenesis in rats (8-10). GO inhibited the growth of mammary and pancreatic neoplasms in rats and hamsters, respectively $(11,12)$, and proved to be an effective adjuvant in the treatment with 5-fluorouracil of human colorectal cancer cells transplanted in Swiss nu/ nu mice (13). $\beta I$ also reduced the incidence of mammary neoplasms in rats $(3,11)$ and, more recently, it was shown to inhibit the number and size of preneoplastic lesions (PNLs) in the colon when administered in the diet to F344

Correspondence: F.S. Moreno, Departamento de Alimentos e Nutrição Experimental, Faculdade de Ciências Farmacêuticas, USP, Bloco 14, Av. Prof. Lineu Prestes, 580, 05508-900 São Paulo, SP, Brasil. Fax: +55-11-3815-4410. E-mail: rmoreno@usp.br 
rats (14). Similarly, other isoprenoids such as perillyl alcohol (15), squalene (16), geranylgeraniol, farnesol, and lanosterol $(17,18)$ also showed chemopreventive activity in a colon carcinogenesis model induced by azoxymethane.

One mechanism of action proposed for the chemopreventive action of isoprenoids is related to the suppression of 3-hydroxy-3-methylglutaryl coenzyme A (HMG-CoA) reductase activity $(6,19)$, which is frequently elevated and deregulated in PNLs and neoplastic tissues (2). The inhibition of HMG-CoA reductase and intermediates of the mevalonate pathway is related to the suppression of cell proliferation and induction of apoptosis $(2,6,20)$. The Bcl-2 family of proteins has also been implicated in cell death induction by dietary isoprenoids $(21,22)$ and reports of changes in expression of $\mathrm{Bcl}-2$ in colon carcinogenesis confirm that this protein may be involved in the primary mechanism of homeostasis in the colonic epithelium (23). Additive and synergistic inhibitory effects have been described after treatment of neoplastic cell lines with a combination of cyclic and acyclic isoprenoids $(24,25)$.

Because $\beta I$ and $\mathrm{GO}$ had chemopreventive activity in different models $(8-10,12)$, including colon carcinogenesis in the case of $\beta \mathrm{I}(14)$, we hypothesized that the combination of $\beta \mathrm{I}$ and $\mathrm{GO}$ could result in synergistic chemopreventive activity. Therefore, we investigated the chemopreventive potential of the combination of $\beta I$ and $\mathrm{GO}$ during the initiation and postinitiation phases of a rat colon carcinogenesis model induced by dimethylhydrazine (DMH). The parameters evaluated included aberrant crypt foci (ACF), which are considered to be PNLs and are widely used as a colon carcinogenesis biomarker (26), plasma concentrations of total cholesterol, DNA damage (Comet test), expression of proliferating cell nuclear antigen (PCNA) and Bcl-2 proteins, and concentrations of $\beta \mathrm{I}$ and $\mathrm{GO}$ in colonic samples.

\section{Material and Methods}

\section{Chemicals}

BI (4-(2,6,6-trimethyl-1-cyclohexen-1-yl)-3(E)-buten-2one; 95\%), GO (trans-3,7-dimethyl-2,6-octadien-1-ol; 98\%)

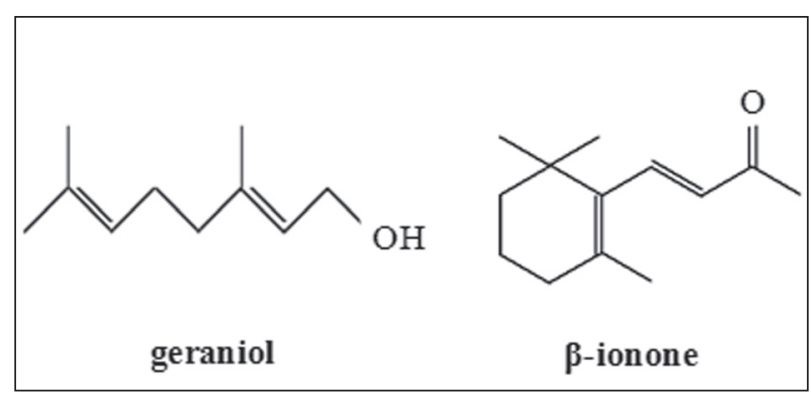

Figure 1. Chemical structure of the acyclic isoprenoid geraniol (trans-3,7-dimethyl-2,6-octadien-1-ol) and the cyclic isoprenoid $\beta$-ionone (4-(2,6,6-trimethyl-1-cyclohexen-1-yl)-3(E)buten-2-one). and $\mathrm{DMH}$ (>99\%) were purchased from Sigma (USA). The commercial diet was purchased from Purina (Brazil), and the corn oil (CO) was from Mazola ${ }^{\circledR}$ (Brazil). The polyclonal anti-Bcl-2 rabbit antibody was purchased from Santa Cruz Biotechnology (USA). The monoclonal anti-PCNA, secondary biotinylated antibody and streptavidin-biotin-peroxidase complex (StrepABComplex/HRP Duet, Mouse/Rabbit) were purchased from Dako (Denmark). The nitrocellulose membrane (Hybond TM-C extra), ECL chemiluminescence kit and ECL-advanced chemiluminescence kit were purchased from Amersham Biosciences (USA). The total plasma cholesterol kit was purchased from BioSystems (Spain). NEPER, T-PER and BCA protein assay kits were purchased from Pierce (USA). All other chemicals were of the highest available quality.

\section{Animals and experimental protocol}

Three-week-old male Wistar rats from the colony of the Faculdade de Ciências Farmacêuticas, Universidade de São Paulo, were used. The animals, initially weighing 40$50 \mathrm{~g}$, were maintained in cages in groups of 4 at a constant temperature $\left(22^{\circ} \mathrm{C}\right)$ and on a 12-h light-dark cycle and received water and commercial diet ad libitum. At the end of a 7-day acclimatization period, with the exception of 6 rats not subjected to any experimental procedure (Normal (N) group), 48 animals (12 animals per group) were treated daily for 9 consecutive weeks with: $\beta \mathrm{I}$ ( $\beta$ I group; $16 \mathrm{mg} / 100$ g body weight), GO (GO group; $25 \mathrm{mg} / 100 \mathrm{~g}$ body weight) or $\beta$ I combined with GO ( $\beta \mathrm{I}+\mathrm{GO}$ group; $\beta \mathrm{I}(16 \mathrm{mg} / 100 \mathrm{~g}$ body weight) plus $\mathrm{GO}$ ( $25 \mathrm{mg} / 100 \mathrm{~g}$ body weight) dissolved in $\mathrm{CO}(0.25 \mathrm{~mL} / 100 \mathrm{~g}$ body weight). Animals receiving only $\mathrm{CO}(0.25 \mathrm{~mL} / 100 \mathrm{~g}$ body weight) were used as controls (CO group). On the 3rd and 4th weeks of treatment, the $\mathrm{CO}, \beta \mathrm{I}$, GO and $\beta I+G O$ groups received ip injections of $\mathrm{DMH}(40$ $\mathrm{mg} / \mathrm{kg}$ body weight) twice a week (27). After 9 weeks of treatment, the animals were euthanized by exsanguination under anesthesia (Figure 2). The study was approved by the Ethics Committee for Animal Research of the Faculty of Pharmaceutical Sciences, University of São Paulo (Protocol \#75). At autopsy, the colons were opened and divided longitudinally into 2 hemicolons; one hemicolonic segment was fixed flat in $70 \%$ ethanol and divided into 2 regions: proximal and distal. The other hemicolonic segment had its mucosa scraped and was stored at $-80^{\circ} \mathrm{C}(28,29)$ for later determination of DNA damage (Comet assay), PCNA and $\mathrm{Bcl}-2$ expression and $\beta \mathrm{I}$ and $\mathrm{GO}$ concentration.

\section{Quantification of ACF in the colonic mucosa}

ACF were scored as previously described (26). Colonic segments were stained for 10 min with $0.02 \%$ methylene blue in phosphate-buffered saline (PBS; $2.7 \mathrm{mM} \mathrm{KCl}, 8.1$ $\mathrm{mM} \mathrm{Na}_{2} \mathrm{PO}_{4}, 1.5 \mathrm{mM} \mathrm{KH}_{2} \mathrm{PO}_{4}, 0.14 \mathrm{M} \mathrm{NaCl}, \mathrm{pH}$ 7.6) (27). Methylene blue-stained ACF, analyzed from the mucosal surface by transmitted light at 40X magnification, appeared as collections of elevated crypts with increased staining and 
expanded pericryptal spaces (26-28). The ACF location (distal or proximal colon) and the multiplicity of each focus (number of crypts/ACF) were recorded.

\section{Total plasma cholesterol concentration}

Blood was collected by puncture of the abdominal aorta at the time of euthanasia. Immediately after collection, it was placed in centrifuge tubes containing $5 \mathrm{mg}$ EDTA and centrifuged at $3500 \mathrm{~g}, 4^{\circ} \mathrm{C}$ for $10 \mathrm{~min}$. Total plasma cholesterol concentration was determined using an enzymatic-spectrophotometric technique (10). Analysis was performed at 500 $\mathrm{nm}$ with a Hitachi U 110 spectrophotometer (Japan).

\section{Colonic DNA strand breakage (single-cell gel electro- phoresis - Comet test)}

Colonic DNA strand breakage was evaluated in colonic mucosa samples stored at $-80^{\circ} \mathrm{C}$ using the Comet assay as described previously (9). The tissues were smoothly homogenized in PBS under refrigeration, and filtered. The isolated cells were then immobilized in a low-melting agarose matrix on a glass slide. The slides were then transferred to the lysis solution (2.5 M NaCl, $100 \mathrm{mM}$ EDTA, $10 \mathrm{mM}$ Trizma Base, $10 \% \mathrm{DMSO}, 1 \% \mathrm{~N}$-laurylsarcosine, $\mathrm{pH}$ adjusted to 10 , and addition of $1 \%$ Triton X-100). After $1 \mathrm{~h}$, the slides were washed three times for 20 min with water and placed in a horizontal electrophoresis unit containing the running buffer $(300 \mathrm{mM}$ $\mathrm{NaOH}$ and $1 \mathrm{mM}$ EDTA, $\mathrm{pH}$ >13) where they remained immersed for $20 \mathrm{~min}$ at $5^{\circ} \mathrm{C}$. Electrophoresis was performed for $20 \mathrm{~min}$ at $0.9 \mathrm{~V} / \mathrm{cm}$ at $5^{\circ} \mathrm{C}$. The resulting comets were neutralized with $0.4 \mathrm{M}$ Tris three times for $5 \mathrm{~min}$ and stained with silver nitrate. Normal rat colonic tissues, treated or not with hydrogen peroxide (HP; $10 \%$ final concentration, 5 min at room temperature and sonication) were used as positive and negative controls, respectively.

The length of the comets was evaluated using a previously described image analysis system $(8,9)$. One hundred nucleoids per animal were randomly analyzed (50 images per slide) and encoded slides were scored blindly. The viability of the colonic mucosa cells was indirectly determined by analyzing the comet images after silver staining.

\section{Apoptosis analysis}

Apoptosis was identified in hematoxylin-eosin (HE)stained proximal and distal colon sections for each animal from the $\mathrm{CO}, \beta \mathrm{I}, \mathrm{GO}$, and $\beta \mathrm{I}+\mathrm{GO}$ groups (27). Apoptosis was evaluated as total number of apoptotic cells in normalappearing colonic crypt areas measured in 10 random microscopic fields consecutive (40X objective). This analysis was performed using an Image QWin Pro Plus Image Analysis System (Leica Imaging Systems Ltd., England) connected to a Leica DM2500 microscope. The image input was performed using a Leica DFC300FX digital CCD camera, and image processing, binarization and measurement were performed using a standard Leica QWin V3 program. Colonic crypt segmentation was performed by setting an automatic threshold level or interactively, by manual tracing, when necessary. The morphological criteria for the identification of apoptotic colonic cells (i.e., with cellular retraction and condensation, condensed or fragmented nuclear chromatin and formation of apoptotic bodies) in HE-stained sections were used as previously described (27). Data are reported as mean number of apoptotic cells per crypt area analyzed $\left(\mathrm{mm}^{2}\right)$ per group.

\section{PCNA and Bcl-2 Western blot analysis}

Total and cytoplasmic protein extracts were prepared from the colonic mucosa samples of the animals using the T-PER and NE-PER reagents, respectively. Protein concentration was determined with the BCA protein assay kit. Samples of $150 \mu \mathrm{g}$ total protein and of $450 \mu \mathrm{g}$ cytoplasmic protein were used for PCNA and Bcl-2 expression analysis, respectively. The samples were separated by electrophoresis on $15 \%$ denaturing polyacrylamide gel (SDS-PAGE) in $1 \mathrm{X}$ Tris-glycine buffer. The proteins were then transferred from the gel to nitrocellulose membranes and blocked with the ECL-advanced kit blocking solution for PCNA analysis or with PBS containing $5 \%$ powdered milk for $\mathrm{Bcl}-2$ analysis, for $1 \mathrm{~h}$. After washing with PBS buffer containing $0.1 \%$ Tween-20, the membranes were incubated overnight at $4^{\circ} \mathrm{C}$ with the primary anti-PCNA antibody $(1: 10,000)$ diluted with the ECL-advanced kit blocking solution or with anti-Bcl-2 antibody (1:500) diluted in milk. The membranes were then incubated with the secondary antibody conjugated to horse radish peroxidase for $1 \mathrm{~h}$ at room temperature. The membranes were developed using the ECL-advanced and ECL kit for PCNA and Bcl-2 analysis, respectively. X-ray films were then exposed to the membranes. To quantify the band intensities, a densitometer (Imaging Densitometer, Model GS-700, Bio-Rad, USA) with specific software (Molecular

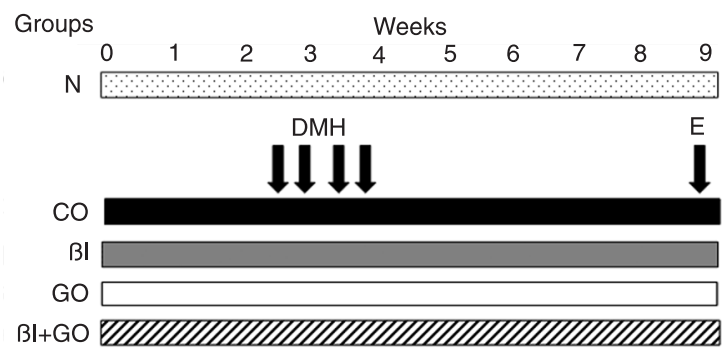

(N) Normal group

(CO) Com oil group (control) $(0.25 \mathrm{~mL} / 100 \mathrm{~g}$ body weight)

(BI) B-ionone group (16 mg/100 g body weight)

(GO) Geraniol group ( $25 \mathrm{mg} / 100 \mathrm{~g}$ body weight)

$\mathbb{Z}($ (BI+GO) B-ionome (16 mg/100 g body weight) + Geraniol (25 $\mathrm{mg} / 100 \mathrm{~g}$ body weight) group

$\mathrm{DMH}$ - 1.2-dimethylhydrazine ( $40 \mathrm{mg} / \mathrm{kg}$ body weight)

E - Euthanasia

Figure 2. Experimental protocol. 
Analyst, Bio-Rad) was used. To control for the amount of protein loaded, the nitrocellulose membrane was stained with Coomassie blue $(8,9,30)$.

\section{Colonic $\beta$ I and $\mathrm{GO}$ concentrations}

$\beta \mathrm{I}$ and $\mathrm{GO}$ quantification was performed by the method of Su et al. (31) with some modifications. Colonic mucosa samples from each group were powdered with liquid $\mathrm{N}_{2}$ and homogenized in a Potter homogenizer with $400 \mu \mathrm{L}$ absolute ethanol plus $10 \mathrm{ng}$ methyl- $\beta$-ionone and $10 \mathrm{ng}$ thimol (internal standard) for the quantification of $\beta \mathrm{I}$ and $\mathrm{GO}$, respectively. Homogenates were centrifuged for $15 \mathrm{~min}$ at $10,000 \mathrm{~g}\left(4^{\circ} \mathrm{C}\right)$,

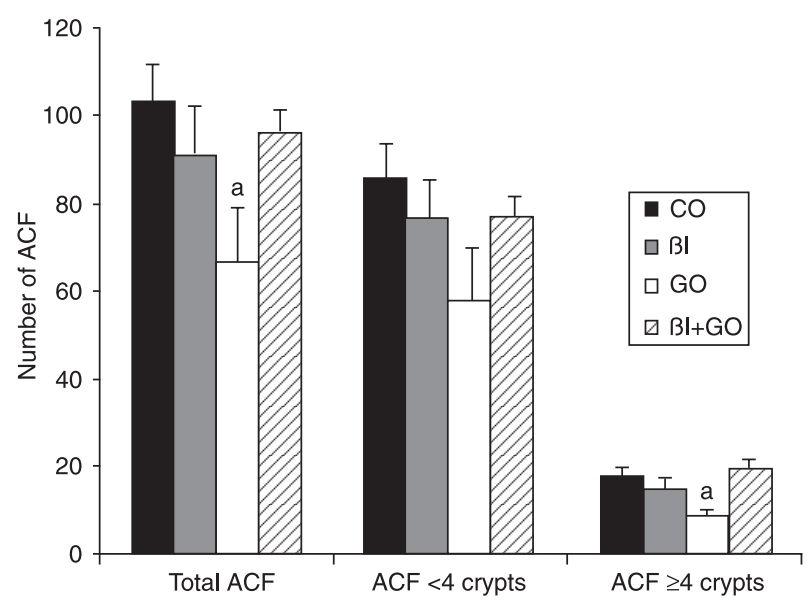

Figure 3. Total number of $A C F$ and number of $A C F<4$ or $A C F \geq 4$ crypts present in the distal colon of rats treated with $\mathrm{CO}, \beta \mathrm{I}, \mathrm{GO}$, or $\beta I+G O$ during the initiation and post-initiation phases of colon carcinogenesis. Doses are given in Figure 2. Data are reported as means \pm SEM. ACF = aberrant crypt foci; $\mathrm{CO}=$ corn oil $(\mathrm{N}$ $=8) ; \beta I=\beta$-ionone $(N=12) ; G O=$ geraniol $(N=11) ; \beta I+G O=$ combination of $\beta I$ and $G O(N=11)$. aP $\leq 0.05$ compared to control (CO group) (Student $t$-test for unpaired data).

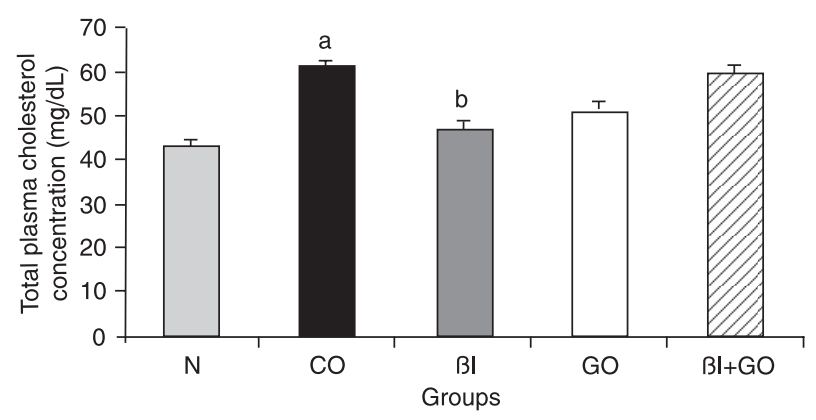

Figure 4. Total plasma cholesterol concentration of $\mathrm{N}$ rats and of animals treated with $\mathrm{CO}, \beta \mathrm{I}, \mathrm{GO}$, or $\beta \mathrm{I}+\mathrm{GO}$ during the initiation and post-initiation phases of colon carcinogenesis. Doses are given in Figure 2. Data are reported as means \pm SEM. $N=$ normal $(N=6) ; C O=$ corn oil $(N=8) ; \beta I=\beta$-ionone $(N=12) ; G O$ = geraniol $(N=11) ; \beta \mid+G O=$ combination of $\beta I$ and $G O(N=11)$. $\mathrm{P} \leq 0.05$ when compared to the ${ }^{\mathrm{a}} \mathrm{N}$ or ${ }^{\mathrm{b}} \mathrm{CO}$ group (Student $t$-test for unpaired data). the supernatants were collected and transferred to clean injection vials and $2 \mu \mathrm{L}$ was injected into a gas chromatography/ mass spectrometry (GC-MS) system. Standard $\beta$ I and GO solutions plus the same amount of internal standard added to the samples were used for the calibration curves that were calculated using the analyte/internal standard peak-area ratios versus the nominal concentrations of each standard. The samples and standards were injected into an HP6890 gas chromatographer (Agilent, USA) equipped with a CP Wax 58 - FFAP (Varian 25 m x 0.32 m x $0.2 \mu \mathrm{m}$ ) column. Injection was done in the splitless mode and the injection port was maintained at $200^{\circ} \mathrm{C}$. The carrier gas used was helium, at a flow rate of $1.0 \mathrm{~mL} / \mathrm{min}$. The oven temperature was maintained at $50^{\circ} \mathrm{C}$ for $3 \mathrm{~min}$ and raised to $250^{\circ} \mathrm{C}$ at $20^{\circ} \mathrm{C} / \mathrm{min}$. The column effluent was monitored by a mass selective detector HP5973 (Agilent) using electron impact ionization with an ion source at $70 \mathrm{~V}$ and $200^{\circ} \mathrm{C}$.

\section{Statistical analysis}

Data are reported as means \pm SEM and all analyses were conducted using the STATISTICA 8.0 software (Statsoft, USA). Differences were considered to be statistically significant when $\mathrm{P}<0.05$.

\section{Results}

\section{Weight gain and diet consumption}

No differences were observed between the $\mathrm{CO}$ (control), $\beta I, G O$ and $\beta I+G O$, groups regarding final body weight and average diet consumption during the 9 weeks of the experiment (data not shown). This suggests that isoprenoids had no toxicity at the doses administered. It is important to emphasize that the doses used $(16 \mathrm{mg} / 100 \mathrm{~g}$ body weight $\beta I$ and $25 \mathrm{mg} / 100 \mathrm{~g}$ body weight GO) were much lower than the respective $L D_{50}\left(L D_{50}\right.$ of $\beta \mathrm{I}=329 \mathrm{mg} / 100 \mathrm{~g}$; $L D_{50}$ of $\mathrm{GO}$ $=360 \mathrm{mg} / 100 \mathrm{~g})(4,5)$.

Quantification of ACF in the proximal and distal colon

The $\beta I, G O$ and $\beta I+G O$ groups did not differ from the $C O$ group in terms of the total number of ACF or ACF $<4$ or ACF $\geq 4$ crypts in the proximal colon.

Figure 3 presents the total number of $A C F$ and the number of ACF $<4$ or ACF $\geq 4$ crypts present in the distal colon of animals from the $\mathrm{CO}, \beta \mathrm{I}, \mathrm{GO}$, and $\beta \mathrm{I}+\mathrm{GO}$ groups. Compared to the $\mathrm{CO}$ group, the GO group showed a decreased ( $\mathrm{P} \leq$ 0.05 ) total number of ACF and ACF $\geq 4$ crypts. However, there was no difference in the number of ACF $<4$ crypts in the distal colon compared to the CO group. Furthermore, no differences were observed between the $\mathrm{CO}, \beta \mathrm{I}$ and $\beta \mathrm{I}+\mathrm{GO}$ groups regarding the total number of $A C F, A C F<4$ or ACF $\geq 4$ crypts in the distal colon.

\section{Total plasma cholesterol concentration}

Figure 4 presents the total plasma cholesterol concentration of the $\mathrm{N}, \mathrm{CO}, \beta \mathrm{I}, \mathrm{GO}$, and $\beta \mathrm{I}+\mathrm{GO}$ groups. Compared 
to the $\mathrm{N}$ group, the $\mathrm{CO}$ group exhibited an increased $(\mathrm{P}<$ $0.05)$ plasma cholesterol concentration. Compared with the $\mathrm{CO}$ group, the $\beta \mathrm{I}$ group exhibited a decreased $(\mathrm{P} \leq 0.05)$ plasma cholesterol concentration, while no differences $(P$ $>0.05$ ) were observed in the $\mathrm{GO}$ and $\beta I+\mathrm{GO}$ groups.

\section{Evaluation of DNA damage in the colonic mucosa}

Figure 5 shows the lengths of the comet of the colonic

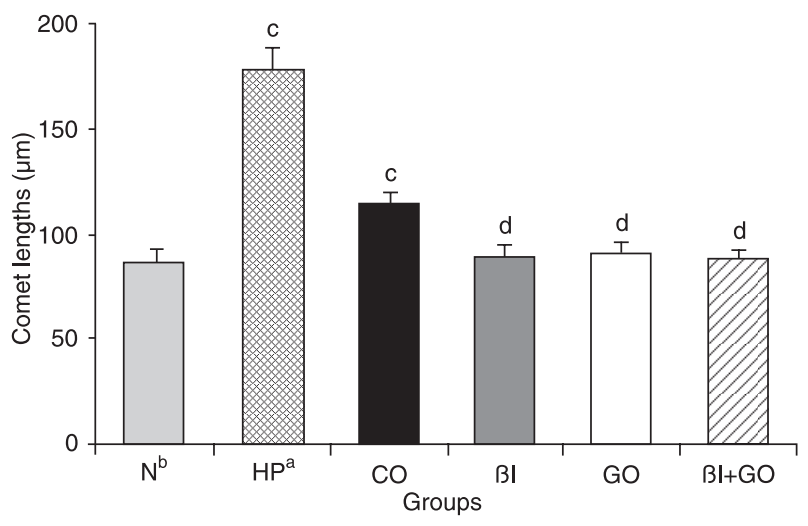

Figure 5. Length of comets of the colonic mucosa of the $\mathrm{N}$ group that was treated or not ${ }^{b}$ with HP, as well as the colonic mucosa of the $\mathrm{CO}, \beta \mathrm{I}, \mathrm{GO}$, or $\beta \mathrm{I}+\mathrm{GO}$ groups during the initiation and postinitiation phases of colon carcinogenesis. Doses are given in Figure 2. Data are reported as means \pm SEM. $N=$ normal $(N=6)$; $\mathrm{CO}=$ corn oil $(\mathrm{N}=8) ; \beta \mathrm{I}=\beta$-ionone $(\mathrm{N}=12) ; \mathrm{GO}=$ geraniol $(\mathrm{N}=$ $11) ; \beta I+G O=$ combination of $\beta I$ and $G O(N=11) ; \mathrm{HP}=$ hydrogen

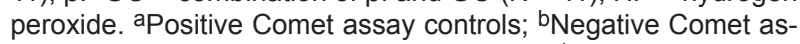
say controls. $\mathrm{P} \leq 0.05$ compared to the ${ }^{\mathrm{C}} \mathrm{N}$ or ${ }^{\mathrm{d}} \mathrm{CO}$ group (Student $t$-test for unpaired data). mucosa of rats from the $\mathrm{N}$ group, treated or not with HP, as well as of the colonic mucosa of rats from the $\mathrm{CO}, \beta \mathrm{I}$, $\mathrm{GO}$, or $\beta I+G O$ groups. Normal rat colonic mucosa samples treated with HP (HP group) showed comets of increased ( $P$ $\leq 0.05$ ) lengths compared to those observed in the untreated ones ( $\mathrm{N}$ group). When compared to the $\mathrm{N}$ group, the $\mathrm{CO}$ group had comets with increased $(P \leq 0.05)$ lengths. When compared to the $\mathrm{CO}$ group, the $\beta \mathrm{I}, \mathrm{GO}$, and $\beta \mathrm{I}+\mathrm{GO}$ groups had comets with reduced $(P \leq 0.05)$ lengths, suggesting a reduction of DNA damage by isoprenoids.

\section{Apoptosis in the colonic mucosa}

Colonic apoptotic cells were easily detected in HEstained sections (Figure 6A). The apoptosis values in the proximal and distal colon from the $\mathrm{CO}, \beta \mathrm{I}, \mathrm{GO}$, and $\beta \mathrm{I}+\mathrm{GO}$ groups are shown in Figure 6B and $\mathrm{C}$. Oral treatment with $\beta I, G O$ or $\beta I+G O$ did not alter the apoptosis levels in the proximal colon when compared to the $\mathrm{CO}$ group $(\mathrm{P}>$ $0.05)$. However, a significant increase in apoptosis levels was detected in the distal colon from the $\mathrm{GO}$ group when compared to the CO group $(P<0.05)$.

\section{Expression of PCNA and $\mathrm{Bcl}-2$ in the colonic mucosa \\ Compared to the $\mathrm{N}$ group, the $\mathrm{CO}$ group showed a 3.1-} fold increase in PCNA protein expression. No differences $(P>0.05)$ were observed between the $C O, \beta I, G O$, and $\beta I+G O$ groups regarding PCNA protein expression.

Figure 7 shows Bcl-2 expression analysis using cytoplasmic protein extracts from the colonic mucosa of rats from the $\mathrm{N}, \mathrm{CO}, \beta \mathrm{I}, \mathrm{GO}$, or $\beta \mathrm{I}+\mathrm{GO}$ groups. Compared to the $\mathrm{N}$ group, the $\mathrm{CO}$ group showed a 2.2-fold increase in $\mathrm{Bcl}-2$ protein expression. Compared to the $\mathrm{CO}$ group, the GO group showed a 0.7 -fold decrease $(P \leq 0.05)$ in $\mathrm{Bcl}-2$
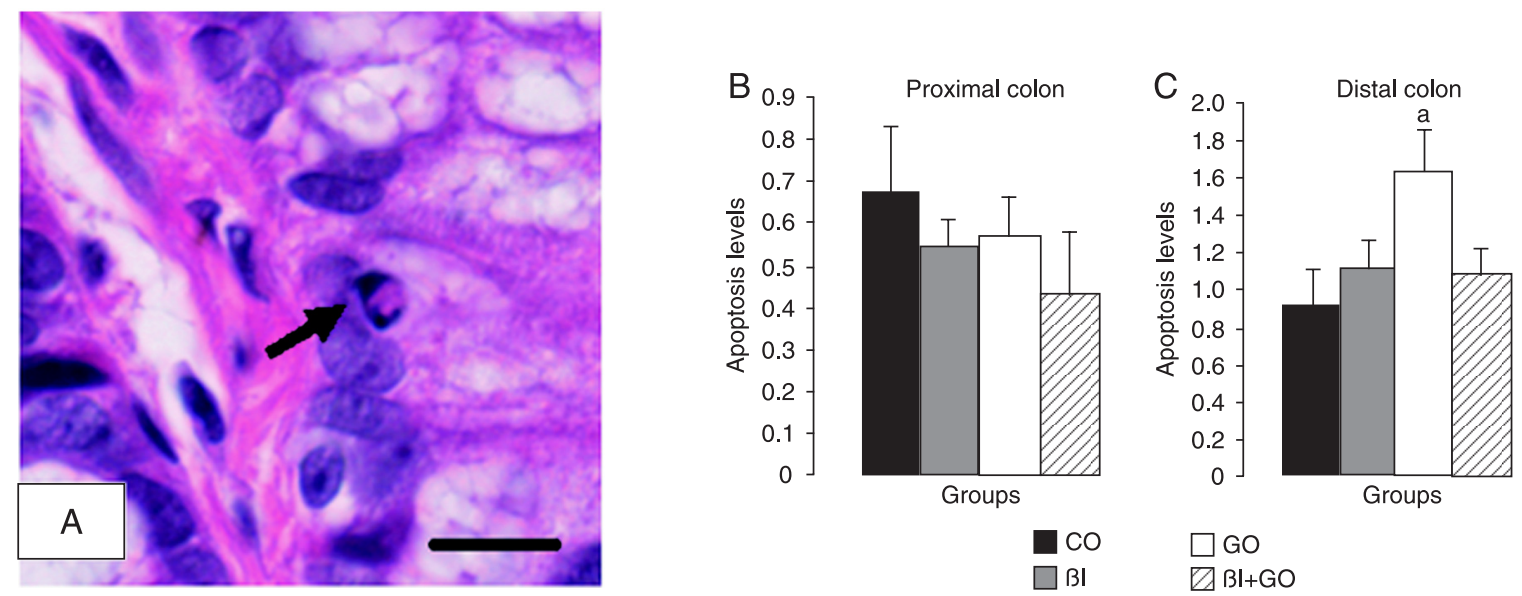

Figure 6. $A$, Photomicrographs of colonic apoptotic cell (arrow) identified in an HE-stained section. $B$, Mean number of apoptotic cells per colonic crypt area $\left(\mathrm{mm}^{2}\right)$ in the proximal colon. $C$, Mean number of apoptotic cells per colonic crypt area $\left(\mathrm{mm}^{2}\right)$ in the distal colon. Doses are given in Figure 2. Bar $=10 \mu \mathrm{m}$. CO = corn oil; $\beta \mathrm{I}=\beta$-ionone; $\mathrm{GO}=$ geraniol; $\beta \mathrm{I}+\mathrm{GO}=$ combination of $\beta$ I and GO. aP $\leq 0.05$ compared to control $(\mathrm{CO})$ (Student $t$-test for unpaired data). 

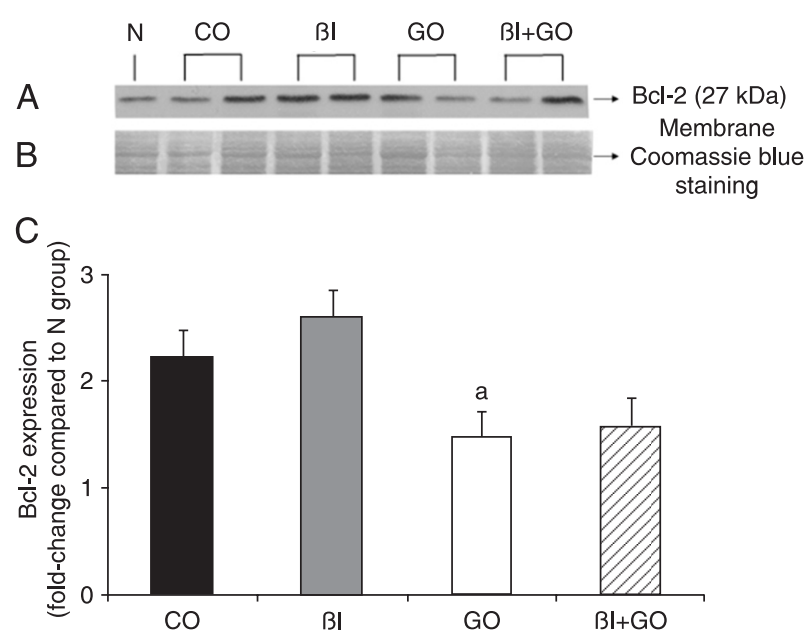

Figure 7. $A, \mathrm{Bcl}-2$ Western blot analysis performed with cytoplasmic proteins extracted from the colonic mucosa of $\mathrm{N}$ rats and of animals treated with $\mathrm{CO}, \beta \mathrm{I}, \mathrm{GO}$, or $\beta \mathrm{I}+\mathrm{GO}$ during the initiation and post-initiation phases of colon carcinogenesis. Representative sample from 1 animal of the $\mathrm{N}$ group and from 2 animals from all other groups; a total of 3 ( $\mathrm{N}$ group) and 6 (all other groups) animals were analyzed. $B$, Coomassie blue staining of the membrane as loading control. C, Quantification of membrane Bcl-2 levels in colon mucosa samples of $\mathrm{N}$ rats and animals treated with $\mathrm{CO}, \beta \mathrm{I}, \mathrm{GO}$, or $\beta I+\mathrm{GO}$ during the initiation and post-initiation phases of colon carcinogenesis. The results are reported in relation to $\mathrm{N}$ animal colon mucosa, whose $\mathrm{Bcl}-2$ protein level was considered as 1 . Data are reported as means \pm SEM. $N=$ normal; $\mathrm{CO}=$ corn oil; $\beta \mathrm{I}=\beta$-ionone; $\mathrm{GO}=$ geraniol; $\beta \mathrm{I}+\mathrm{GO}=$ combination of $\beta \mathrm{I}$ and $\mathrm{GO}$. aP $\leq 0.05$ compared to the $\mathrm{CO}$ group (Student $t$-test for unpaired data).

protein expression while no differences $(P>0.05)$ were observed in the $\beta I$ and $\beta \mid+G O$ groups.

\section{Concentration of $\beta I$ and $G O$ in the colonic mucosa}

$\beta$ I was not detected in the $\mathrm{N}, \mathrm{CO}$ or GO groups. Compared to the $\mathrm{CO}$ group, the $\beta \mathrm{I}$ and $\beta \mathrm{I}+\mathrm{GO}$ groups had higher $(P \leq 0.05)$ colonic mucosa concentrations of $\beta I$. Compared to the $\beta I$ group, the $\beta I+G O$ group had a lower $(P \leq 0.05)$ colonic mucosa concentration of $\beta$ I. There was no difference $(P>0.05)$ in the colonic mucosa concentration of $\mathrm{GO}$ between the $\mathrm{N}$ and $\mathrm{CO}$ groups. Compared to the $\mathrm{CO}$ group, the GO group had a higher $(P \leq 0.05)$ colonic mucosa concentration of $\mathrm{GO}$, while no differences were observed in the $\beta I$ and $\beta I+G O$ groups. Compared to the GO group, the $\beta I+G O$ group showed a lower $(P \leq 0.05)$ colonic mucosa concentration of GO.

\section{Discussion}

The distal portion of the colon is the region where the incidence of neoplasms is most frequent in both rats and humans $(32,33)$. The new data presented here showing that treatment with $\mathrm{GO}$ reduced the total number of $\mathrm{ACF}$ in this region, as well as the number of $A C F \geq 4$ crypts, lesions with a more advanced and aggressive phenotype (33), reinforce the idea that acyclic isoprenoids may be a chemopreventive agent against colon carcinogenesis. To the best of our knowledge, in vivo studies of chemoprevention with $\mathrm{GO}$ have only been conducted in liver, breast and pancreas carcinogenesis models, with inhibition of hepatic PNLs $(9,10)$ and mammary $(11,34)$ and pancreatic $(12)$ neoplastic lesions, respectively. Recently, $\beta$ I was reported to have chemopreventive activity in liver $(8,10)$, breast $(3,11)$ and colon (14) carcinogenesis. However, inhibition of total ACF and of ACF $<4$ or $A C F \geq 4$ crypts by $\beta$ I was not observed in the present study. Differences in the experimental design, such as the type of carcinogen, dose and mode of administration of $\beta I$ and the strain of animals employed, could explain the differences in the results obtained by Janakiram et al. (14) and by us. Unexpectedly, the combination of $\beta I$ and GO did not provide chemopreventive effects.

On the basis of in vitro studies conducted with combinations of isoprenoids, it has been proposed that the less potent compound could attenuate the tumor-suppressive action of the more potent one (25). We investigated whether this absence of chemoprevention was due to alterations in the distribution of isoprenoids. We determined the concentrations of $\beta I$ and $G O$ in the colonic mucosa. Treatment with each compound individuals increased their respective concentration in the colonic mucosa. Animals treated with a mixture of the isoprenoids showed that the $\beta$ I plus GO had lower concentrations compared to animals that were given $\beta$ I and GO individually. It is possible that the reduced concentration of GO in the colonic mucosa was not sufficient to attain protective effects, suggesting that, when considering the combination of isoprenoids as a chemopreventive strategy, bioavailability issues should be considered.

Loss of the regulatory mechanism of HMG-CoA reductase and increase in cholesterol synthesis have been reported to occur during carcinogenesis (6). This could explain the higher cholesterol concentration in the $\mathrm{CO}$ group, as compared to the $\mathrm{N}$ group. Treatment of birds, rats and mice with isoprenoids such as geranylgeraniol, limonene or $\beta \mathrm{I}$ resulted in the reduction of HMG-CoA reductase activity that was accompanied by a decrease in plasma cholesterol $(8,35,36)$. Adecrease in the plasma total cholesterol was observed by us in the $\beta I$ group. Although this cyclic isoprenoid did not have chemopreventive activity, its hypocholesterolemic effect should be highlighted. The chemopreventive activities of GO were not accompanied by a decrease in plasma cholesterol concentrations. Similar results were observed by others after treatment with farnesol, lanosterol and squalene of animals with colon carcinogenesis, and with $\mathrm{GO}$ in pancreas carcinogenesis $(12,16,18)$. As previously reported $(9,19,37)$, the chemopreventive effect of GO may not involve the inhibition of HMG-CoA reductase activity. 
Dietary isoprenoids such as $\beta \mathrm{I}$ and $\mathrm{GO}$ have been shown to have antioxidant properties $(14,24,38)$. Treatment with these isoprenoids, individually or in combination, reduced DNA damage although only $\mathrm{GO}$ exhibited anticarcinogenic effects. It is important to mention that the Comet assay was performed under alkaline conditions that enable the detection of single-and double-stranded breaks, incomplete repair sites and alkali-labile sites, extending the amount of damage that can be detected when compared to neutral conditions (39). These results suggest that antioxidant effects are not involved in the chemopreventive activity of $\mathrm{GO}$ during colon carcinogenesis. Since the induction of apoptosis could be associated with the anticarcinogenic effects of $G O(9,10)$, colonic apoptotic cells were quantified in the present study using established morphological criteria (27). Although GO inhibited DNA damage, the isoprenoid induced apoptosis specifically in the distal colon, suggesting that cell death induction could represent an important feature of the protective effects of GO.

Increase in the anti-apoptotic Bcl-2 protein occurs in the initial phases of colon carcinogenesis (23), as also observed in the present study. Only the GO group exhibited lower levels of $\mathrm{Bcl}-2$, suggesting that the inhibition of this protein could have a relevant role in apoptosis induction by this isoprenoid. The induction of apoptosis via the Bcl-2 family of proteins has been identified as one of the main mechanisms of action of isoprenoids, as observed for perillyl alcohol, geranylgeraniol and farnesol $(21,22)$. It is important to highlight the lack of in vivo studies addressing

\section{References}

1. Huxley RR, Ansary-Moghaddam A, Clifton P, Czernichow S, Parr CL, Woodward M. The impact of dietary and lifestyle risk factors on risk of colorectal cancer: a quantitative overview of the epidemiological evidence. Int J Cancer 2009; 125: 171-180.

2. Elson CE, Peffley DM, Hentosh P, Mo H. Isoprenoid-mediated inhibition of mevalonate synthesis: potential application to cancer. Proc Soc Exp Biol Med 1999; 221: 294-311.

3. Liu JR, Sun XR, Dong HW, Sun $\mathrm{CH}$, Sun WG, Chen $B Q$, et al. Beta-ionone suppresses mammary carcinogenesis, proliferative activity and induces apoptosis in the mammary gland of the Sprague-Dawley rat. Int J Cancer 2008; 122: 2689-2698.

4. Lalko J, Lapczynski A, McGinty D, Bhatia S, Letizia CS, Api AM. Fragrance material review on beta-ionone. Food Chem Toxicol 2007; 45 (Suppl 1): S241-S247.

5. Lapczynski A, Bhatia SP, Foxenberg RJ, Letizia CS, Api AM. Fragrance material review on geraniol. Food Chem Toxicol 2008; 46 (Suppl 11): S160-S170.

6. Mo H, Elson CE. Studies of the isoprenoid-mediated inhibition of mevalonate synthesis applied to cancer chemotherapy and chemoprevention. Exp Biol Med 2004; 229: 567-585.

7. Carnesecchi S, Schneider Y, Ceraline J, Duranton B, Gosse the capacity of apoptosis modulation by GO, as induced in hepatic PNL $(9,10)$. Moreover, since apoptosis is a cellular event that involves activation and/or suppression of various gene families (23), it would be important to determine the influence of GO on other members of the Bcl-2 family, including pro-apoptotic ones such as Bax (22).

In the present study, an increase in PCNA protein was observed in rats subjected to colon carcinogenesis, which could indicate an increase in cell proliferation (40). On the other hand, none of the treatments with isoprenoids reduced the expression of this protein, suggesting that cell proliferation inhibition is not part of the chemopreventive activity of GO.

The present study advances our knowledge regarding the potential of dietary isoprenoids for the chemoprevention of colon carcinogenesis. GO represents a promising agent with inhibitory actions on colonic PNLs that are described here for the first time. Surprisingly, $\beta$ I had little or no activity. Although the combination of cyclic and acyclic isoprenoids has been suggested as a synergistic chemopreventive strategy, issues such as bioavailability should be considered.

\section{Acknowledgments}

The authors are indebted to Miss Silvania M.P. Neves, responsible for the production of experimental animals of Faculdade de Ciências Farmacêuticas, Universidade de São Paulo, for the care and maintenance of the animals. Research supported by FAPESP, CAPES, and CNPq.
F, Seiler N, et al. Geraniol, a component of plant essential oils, inhibits growth and polyamine biosynthesis in human colon cancer cells. J Pharmacol Exp Ther 2001; 298: 197200.

8. de Moura Espindola R, Mazzantini RP, Ong TP, de Conti A, Heidor R, Moreno FS. Geranylgeraniol and beta-ionone inhibit hepatic preneoplastic lesions, cell proliferation, total plasma cholesterol and DNA damage during the initial phases of hepatocarcinogenesis, but only the former inhibits NFkappaB activation. Carcinogenesis 2005; 26: 1091-1099.

9. Ong TP, Heidor R, de Conti A, Dagli ML, Moreno FS. Farnesol and geraniol chemopreventive activities during the initial phases of hepatocarcinogenesis involve similar actions on cell proliferation and DNA damage, but distinct actions on apoptosis, plasma cholesterol and HMGCoA reductase. Carcinogenesis 2006; 27: 1194-1203.

10. Cardozo MT, de Conti A, Ong TP, Scolastici C, Purgatto E, Horst MA, et al. Chemopreventive effects of beta-ionone and geraniol during rat hepatocarcinogenesis promotion: distinct actions on cell proliferation, apoptosis, HMGCoA reductase, and RhoA. J Nutr Biochem 2010 [Epub ahead of print].

11. Yu SG, Anderson PJ, Elson CE. Efficacy of beta-ionone in the chemoprevention of rat mammary carcinogenesis. $J$ Agric Food Chem 1995; 43: 2144-2147. 
12. Burke YD, Stark MJ, Roach SL, Sen SE, Crowell PL. Inhibition of pancreatic cancer growth by the dietary isoprenoids farnesol and geraniol. Lipids 1997; 32: 151-156.

13. Carnesecchi S, Bras-Goncalves R, Bradaia A, Zeisel M, Gosse F, Poupon MF, et al. Geraniol, a component of plant essential oils, modulates DNA synthesis and potentiates 5-fluorouracil efficacy on human colon tumor xenografts. Cancer Lett 2004; 215: 53-59.

14. Janakiram NB, Cooma I, Mohammed A, Steele VE, Rao $C V$. Beta-ionone inhibits colonic aberrant crypt foci formation in rats, suppresses cell growth, and induces retinoid $X$ receptor-alpha in human colon cancer cells. Mol Cancer Ther 2008; 7: 181-190.

15. Reddy BS, Wang CX, Samaha H, Lubet R, Steele VE, Kelloff GJ, et al. Chemoprevention of colon carcinogenesis by dietary perillyl alcohol. Cancer Res 1997; 57: 420-425.

16. Rao CV, Newmark HL, Reddy BS. Chemopreventive effect of squalene on colon cancer. Carcinogenesis 1998; 19: 287290.

17. Wargovich MJ, Jimenez A, McKee K, Steele VE, Velasco M, Woods J, et al. Efficacy of potential chemopreventive agents on rat colon aberrant crypt formation and progression. Carcinogenesis 2000; 21: 1149-1155.

18. Rao CV, Newmark HL, Reddy BS. Chemopreventive effect of farnesol and lanosterol on colon carcinogenesis. Cancer Detect Prev 2002; 26: 419-425.

19. Duncan RE, Lau D, El-Sohemy A, Archer MC. Geraniol and beta-ionone inhibit proliferation, cell cycle progression, and cyclin-dependent kinase 2 activity in MCF-7 breast cancer cells independent of effects on HMG-CoA reductase activity. Biochem Pharmacol 2004; 68: 1739-1747.

20. Elson CE. Suppression of mevalonate pathway activities by dietary isoprenoids: protective roles in cancer and cardiovascular disease. J Nutr 1995; 125: 1666S-1672S.

21. Takeda Y, Nakao K, Nakata K, Kawakami A, Ida H, Ichikawa $\mathrm{T}$, et al. Geranylgeraniol, an intermediate product in mevalonate pathway, induces apoptotic cell death in human hepatoma cells: death receptor-independent activation of caspase-8 with down-regulation of Bcl-xL expression. Jpn J Cancer Res 2001; 92: 918-925.

22. Burke YD, Ayoubi AS, Werner SR, McFarland BC, Heilman $\mathrm{DK}$, Ruggeri BA, et al. Effects of the isoprenoids perillyl alcohol and farnesol on apoptosis biomarkers in pancreatic cancer chemoprevention. Anticancer Res 2002; 22: 31273134.

23. Huerta S, Goulet EJ, Livingston EH. Colon cancer and apoptosis. Am J Surg 2006; 191: 517-526.

24. He L, Mo H, Hadisusilo S, Qureshi AA, Elson CE. Isoprenoids suppress the growth of murine B16 melanomas in vitro and in vivo. J Nutr 1997; 127: 668-674.

25. Mo H, Elson CE. Apoptosis and cell-cycle arrest in human and murine tumor cells are initiated by isoprenoids. $J$ Nutr 1999; 129: 804-813.

26. Bird RP. Observation and quantification of aberrant crypts in the murine colon treated with a colon carcinogen: preliminary findings. Cancer Lett 1987; 37: 147-151.
27. Dias MC, Spinardi-Barbisan AL, Rodrigues MA, de Camargo $\mathrm{JL}$, Teran E, Barbisan LF. Lack of chemopreventive effects of ginger on colon carcinogenesis induced by 1,2-dimethylhydrazine in rats. Food Chem Toxicol 2006; 44: 877-884.

28. Wali RK, Khare S, Tretiakova M, Cohen G, Nguyen L, Hart $J$, et al. Ursodeoxycholic acid and $F(6)-D(3)$ inhibit aberrant crypt proliferation in the rat azoxymethane model of colon cancer: roles of cyclin D1 and E-cadherin. Cancer Epidemiol Biomarkers Prev 2002; 11: 1653-1662.

29. Davidson LA, Brown RE, Chang WC, Morris JS, Wang N, Carroll RJ, et al. Morphodensitometric analysis of protein kinase $\mathrm{C}$ beta(II) expression in rat colon: modulation by diet and relation to in situ cell proliferation and apoptosis. Carcinogenesis 2000; 21: 1513-1519.

30. Wobbe L, Blifernez O, Schwarz C, Mussgnug JH, Nickelsen $\mathrm{J}$, Kruse O. Cysteine modification of a specific repressor protein controls the translational status of nucleus-encoded LHCII mRNAs in Chlamydomonas. Proc Natl Acad Sci U S A 2009; 106: 13290-13295.

31. Su E, Zhang NN, Ho PC. Determination of tributyrin and its metabolite butyrate in Wistar rat plasm samples by gas chromatography/mass spectrometry. Mass Spectrometry 2004; 18: 2217-2222.

32. Pretlow TP, Barrow BJ, Ashton WS, O'Riordan MA, Pretlow TG, Jurcisek JA, et al. Aberrant crypts: putative preneoplastic foci in human colonic mucosa. Cancer Res 1991; 51: 1564-1567.

33. Bird RP. Role of aberrant crypt foci in understanding the pathogenesis of colon cancer. Cancer Lett 1995; 93: 5571.

34. Elson CE, Yu SG. The chemoprevention of cancer by mevalonate-derived constituents of fruits and vegetables. $J$ Nutr 1994; 124: 607-614.

35. Qureshi AA, Mangels WR, Din ZZ, Elson CE. Inhibition of hepatic mevalonate biosynthesis by the monoterpene $\mathrm{d}$ limonene. J Agric Food Chem 1988; 36: 1220-1224.

36. Yu SG, Abuirmeileh NM, Qureshi AA, Elson CE. Dietary beta-ionone suppresses hepatic 3-hydroxy-3-methylglutaryl coenzyme A reductase activity. J Agric Food Chem 1994; 42 : 1493-1496.

37. Carnesecchi S, Bradaia A, Fischer B, Coelho D, SchollerGuinard M, Gosse F, et al. Perturbation by geraniol of cell membrane permeability and signal transduction pathways in human colon cancer cells. J Pharmacol Exp Ther 2002; 303: 711-715.

38. Hierro I, Valero A, Perez P, Gonzalez P, Cabo MM, Montilla MP, et al. Action of different monoterpenic compounds against Anisakis simplex s.I. L3 larvae. Phytomedicine 2004; 11: $77-82$.

39. Collins AR. The comet assay for DNA damage and repair: principles, applications, and limitations. Mol Biotechnol 2004; 26: 249-261.

40. Wu B, Iwakiri R, Ootani A, Tsunada S, Fujise T, Sakata Y, et al. Dietary corn oil promotes colon cancer by inhibiting mitochondria-dependent apoptosis in azoxymethane-treated rats. Exp Biol Med 2004; 229: 1017-1025. 